\title{
DISEMINASI INFORMASI DALAM PENERIMAAN SISWA BARU BERBASIS ANDROID PADA SMA NEGERI ABUNG TINGGI LAMPUNG UTARA
}

\author{
Novrianto, Sumarsono, Yuli Indrianingsih \\ Jurusan Teknik Informatika \\ Sekolah Tinggi Teknologi Adisutjipto Yogyakrta \\ Informatika@stta.ac.id
}

\begin{abstract}
Information regarding the admission of new students in a school is very important to support the smooth reception of new students. Good information distribution process, will improve the quality of education in a school. Application of these new students is a solution that can parents help their parents in distributing information about the graduation of their students in a school. The application supports the announcement of the distribution process before the announcement of new admissions at the school run. This application was developed using Java programming language, assisted by Net.bin for Android Operating System environment. This method is based on client-server, where mobile devices like cell phones or netbooks as a web server as a client and server. Parents are parents who have Android-based mobile devices, can use this application to support the admission of new students. Android mobile applications can make it easier for parents to see the announcement of new admissions, thereby saving time getting to know their students are accepted or not on SMA High Abung, North Lampung.
\end{abstract}

Keywords: New Admission Application, Mobile, Android.

\section{Pendahuluan}

Pendidikan merupakan salah satu langkah awal bagi seseorang untuk memperoleh kesuksesan. Karena, dalam dunia pendidikan diberikan bekal hidup berupa ilmu pengetahuan serta pengalaman yang tiada habisnya. Secara tidak langsung hal tersebut membuat lebih aktif, serta giat berpartisipasi dalam perkembangannya. Sebagai salah satu contoh, bisa dilihat dalam segi sumber daya manusia yang ada di negara Indonesia. Secara perlahan, pekerjaan yang membutuhkan tenaga manusia mulai tergeser seiring dengan penggunaan sistem atau mesin yang lebih canggih. Sistem atau mesin tersebut membantu untuk mendukung mobilitas sehingga meringankan perkerjaan terutama hal menyangkut mengenai Informasi dan komunikasi penerimaan siswa baru.

\section{Landasan Teori}

Android adalah kumpulan perangkat lunak yang ditujukan bagi perangkat bergerak mencakup sistem operasi, middleware, dan aplikasi kunci. Android Standart Development Kid (SDK) menyediakan perlengkapan dan Application Programming Interface (API) yang 
diperlukan untuk mengembangkan aplikasi pada platform Android menggunakan bahasa pemrograman Java. (Sayed Y. Hashimi and Satya Komatineni, 2009)

Android dikembangkan oleh Google bersama Open Handset Allience (OHA) yaitu aliansi perangkat selular terbuka yang terdiri dari 47 perusahaan Hardware, Software dan perusahaan telekomunikasi ditujukan untuk mengembangkan standar terbuka bagi perangkat selular.

\section{Web service}

Web service adalah suatu sistem perangkat lunak yang dirancang untuk mendukung interoperabilitas dan interaksi antar sistem pada suatu jaringan. Web service digunakan sebagai suatu fasilitas yang disediakan oleh suatu web site untuk menyediakan layanan (dalam bentuk informasi) kepada sistem lain, sehingga sistem lain dapat berinteraksi dengan sistem tersebut melalui layanan-layanan (service) yang disediakan oleh suatu sistem yang menyediakan web service. Web service menyimpan data informasi dalam format XML, sehingga data ini dapat diakses oleh sistem lain walaupun berbeda platform, sistem operasi, maupun bahasa compiler. Perbedaan antara web service dengan web site. Web Site:

a. Memiliki web interface

b. Dibuat untuk berinteraksi langsung dengan user

c. Dibuat untuk bekerja pada web browser

Web Service :

a. Tidak memiliki tampilan atau interface yang bagus

b. Dibuat untuk berinteraksi langsung dengan aplikasi yang lain baik beda sistem operasi atau konsep sekalipun.

c. Dibuat untuk bekerja pada semua tipe client aplikasi

\section{Perancangan Sistem}

Pada gambar 1 perancangan alur program memberikan gambaran secara visual melalui sebuah gambar untuk dapat memahami bagai mana sistem penerimaan siswa baru berkerja dalam pencarian data yang ada di server.

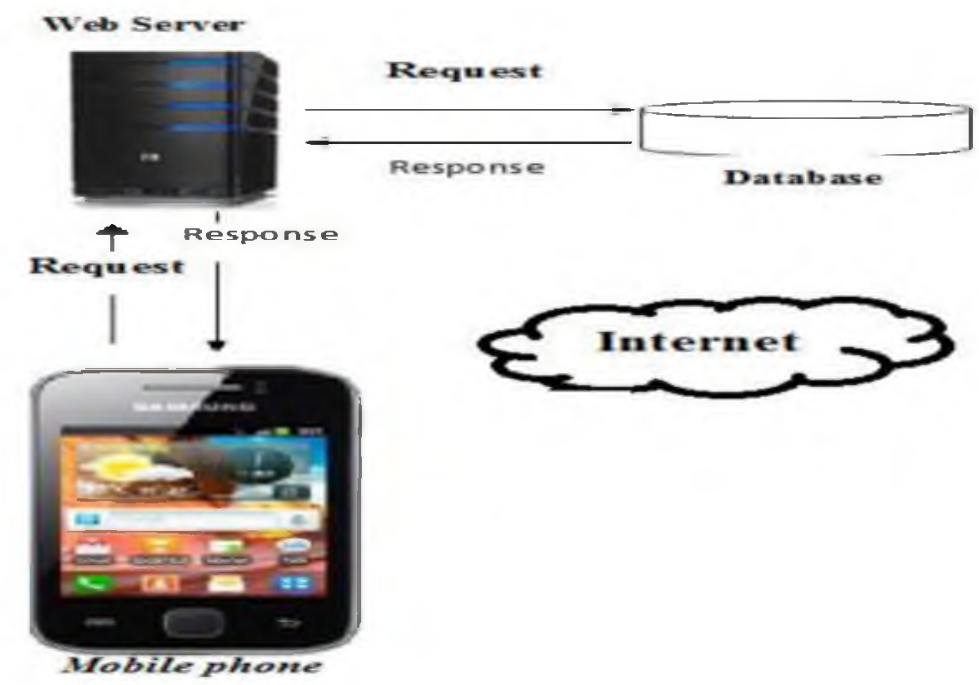

Gambar 1 Konsep Aplikasi Android Penerimaan siswa baru 


\section{Fowchart Sistem Aplikasi penerimaan siswa baru}

Dalam aliran atau flowchart merupakan serangkaian bagan-bagan yang menggambarkan aliran program. Pada diagram aliran ini digambarkan urutan prosudur dalam program peneriman siswa baru berbasis Android

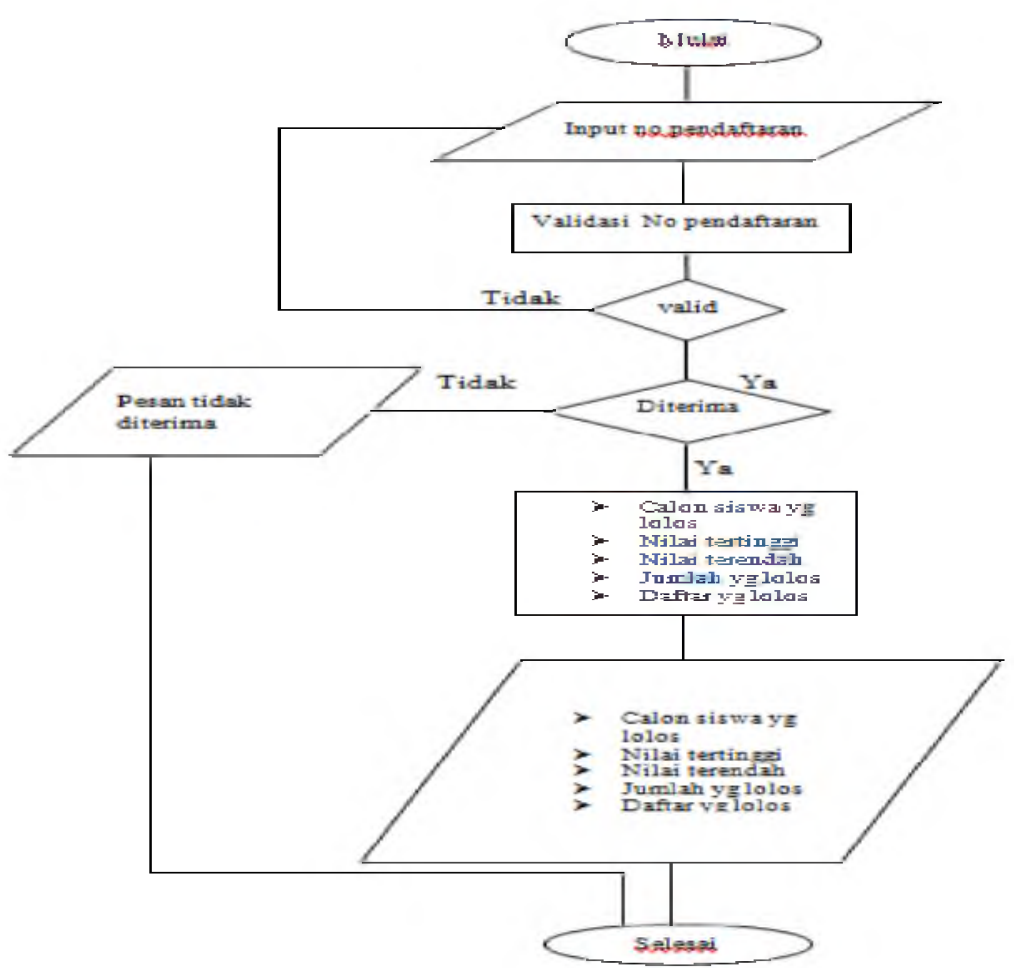

Gambar 2 Fowchart Sistem Aplikasi penerimaan siswa baru

\section{Implementasi Aplikasi penerimaan siswa baru Android}

Implementasi adalah tahapan pengujian sistem setelah perencanaan, penyiapan data dan pembuatan program. Pengujian dilakukan mulai dari kegiatan pengetesan program dari awal, pengisian data hingga cetak hasil.

\section{Tampilan Login}

Tampilan awal adalah tampilan menu login User atau pengguna, login user menggunakan No.pendaftaran penerimaan siswa baru, tampilan dapat dilihat pada gambar 4 . Hasilnya adalah menentukan siswa dieterima atau tidaknya.

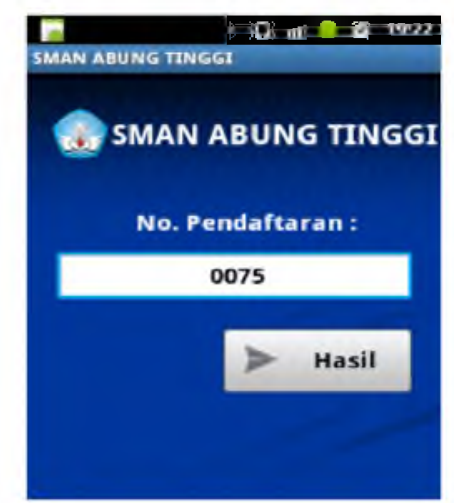

Gambar 4. Tampilan Login 


\section{Tampilan menu calon siswa yang berhasil lolos}

Tampilan menu calon siswa yang berhasil lolos yaitu informasi nama calon siswa yang berhasil lolos di SMA Negeri Abung Tinggi, tampilan dapat dilihat pada gambar 5.

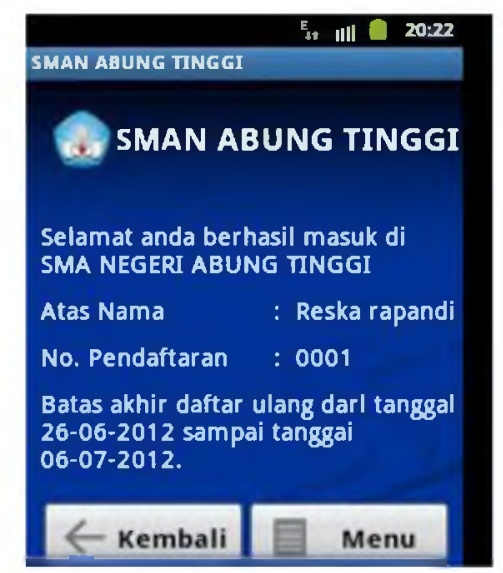

Gambar 5.Tampilan menu calon siswa yang berhasil lolos

\section{Tampilan calon siswa yang belum berhasil lolos}

Tampilan calon siswa belum berhasil lolos yaitu menampilkan informasi pemberitahuan bahawa calon siswa belom bisa bergabung di SMA Negeri Abung Tinggi, tampilan dapat di lihat pada gambar 6 .

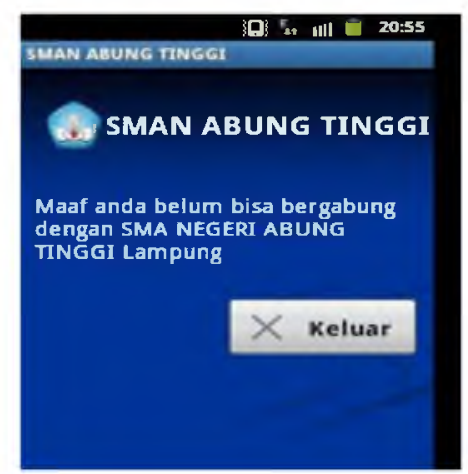

Gambar 6. Tampilan Calon Siswa Yang Belum Berhasil Lolos

\section{Analisa}

Analisa dilakukan dari hasil uji coba aplikasi ini yaitu penerimaan siswa baru di SMA Negeri Abung Tinggi, Lampung Utara. Hasil analisa ini yang menentukan ketepatan program dalam memberikan informasi kepada user/ kepada orang tua wali murid. Berikut ini adalah analisa penerimaan siswa baru hasil uji coba yang telah dilakukan. Analisa ini dilakukan dengan tujuan untuk menggambarkan informasi tentang kelulusan penerimaan siswa baru di SMA Negeri Abung Tinggi, Lampung Utara. Penggunaan mobile android memudahkan orang tua wali murid dalam mendapatkan informasi kelulusan penerimaan siswa baru di SMA Negeri Abung Tinggi,Lampung Utara. Sehingga orang tua wali murid dapat mengakses informasi penerimaan siswa baru dimana saja tidak perlu harus mendatangi sekolah untuk mendapatkan informasi kelulusan. 
Jadi aplikasi penerimaan siswa baru ini berjalan berdasarkan koneksi internet, apabila sinyalnya bagus maka koneksi internet juga otomatis bagus dan aplikasinya pun berjalan dengan baik. Tapi apabila sinyalnya kurang mendukung atau lemah maka koneksi internet juga akan lemah dan aplikasinya akan berjalan lambat.

\section{Kesimpulan}

1. Aplikasi ini membantu orang tua wali murid untuk mengetahui anak didiknya lulus atau tidak pada SMA Negeri Abung Tinggi Lampung Utara.

2. Aplikasi ini memudahkan para orang tua wali murid untuk melihat ke lulusan sehingga tidak harus menunggu pengumuman di sekolah.

3. Di luar aplikasi ini tetap membutuhkan campur tangan user / orang tua murid. Dalam hal ini adalah user (orang tua wali murid) sebagai pengguna, karena aplikasi ini hanya sebagai pencarian data.

\section{Daftar Pustaka}

Fowler, Martin. 2005. UML Distilled 3th Ed. Panduan Singkat Bahasa Permodelan Objek Standar. Yogyakarta: Penerbit ANDI.

Kristanto, Andri. 2004. Rekayasa Perangkat Lunak (Konsep Dasar). Yogyakarta : Gaya Media.

Kustanto dan T. Saputro., 2008., Membangun Server Internet dengan Mikrotik OS, Penerbit Grava Media, Yogyakarta, Indonesia.

Mulyadi., 2010., Membuat Aplikasi untuk Android, Multimedia Center Publishing, Yogyakarta, Indonesia.

Sayed Y. Hashimi and Satya Komatineni, 2009, Pro Android, Apress Inc.

Sofana., 2009., Cisco CCNA \& Jaringan Komputer, Informatika, Bandung, Indonesia. 
Novrianto. Sumarsono, Yuli Indrianingsih 